\title{
Spectrophotometric Determination of Kelthane in Environmental Samples
}

\author{
Etesh K. Janghel ${ }^{1}$, Y. Pervez ${ }^{2}$ \\ ${ }^{1}$ Department of Applied Chemistry, Ashoka Institute of Technology \& Management, Gram-Torankatta, Post-Somni, \\ Rajnandgaon, India \\ ${ }^{2}$ Department of Applied Chemistry, Chhatrapati Shivaji Institute of Technology, Durg, India \\ E-mail: eteshkumar@rediffmail.com \\ Received September 27, 2010; revised January 10, 2011; accepted January 20, 2011
}

\begin{abstract}
Sensitive spectrophotometric method for determination of kelthane in sub parts per million level is described, which is based on Fujiwara reaction. Kelthane on alkaline hydrolysis gives chloroform, which can be reacted with pyridine to produce red colour. The colour is discharged by addition of glacial acetic acid. Then Benzidine (4,4'-Bianiline) reagent is added due to which a yellowish-red colour is formed which has an absorption maximum at $490 \mathrm{~nm}$. Beer's law is obeyed in the range of $3.3-26.0 \mu \mathrm{g}(0.13-1.04 \mathrm{ppm})$ of Kelthane per $25 \mathrm{ml}$ of final solution. The molar absorptivity and Sandell's sensitivity were found to be $4.32 \times 10^{5}$ $\mathrm{L} \cdot \mathrm{mol}^{-1} \cdot \mathrm{cm}^{-1}$ and $0.022 \mu \mathrm{g} \cdot \mathrm{cm}^{-2}$ respectively. The method is found to be free from interferences of other organochlorine pesticides and various co-pollutants and can be successfully applied for the determination of kelthane in environmental samples.
\end{abstract}

Keywords: Spectrophotometry, Kelthane, Acaricide, Benzidine, Environmental Samples

\section{Introduction}

Kelthane is a well known acaricide of organochlorine group of pesticides, chemically it is known as 4-4'dichloro-alpha trichloromethyl benzhydrol [1] Kelthane appears to be effective against a wide range of mite species and is a well known miticide. It is also effective against tetrachid, mites, cydamen, broad, mites, European red spider, apple-rust, cherry-rust, tomato-rust, and various other fruits and vegetable rusts [2].

Field studies indicate that dicofol persists in soil for at least four years after application. The residue of kelthane accumulates in rotational crops. Due to very long persistency of residue of this material, the use of kelthane is recommended on slow growing crops, i.e. citrus fruits. It has been proved that kelthane is a sever irritant $[3,4]$. The National Cancer Institute suggests the possibility of kelthane as oncogen. The toxic effect of kelthane shows general weakness, comma, affects sex hormones, inhibition of aromatose activity and death in animal. It is a contact herbicide with initial toxicity. It has a moderate acute oral toxicity. The oral $\mathrm{LD}_{50}$ in rat is $809 \mathrm{mg} / \mathrm{kg}$ and $1870 \mathrm{mg} / \mathrm{kg}$ body weights for rabbit [2]. The tolerance level of dicofol in vegetable is $1 \mathrm{mg} / \mathrm{kg}[5-7]$.
Several instrumental techniques i.e. GLC with Electron Capture detector [8], Voltammery [9] Neutron activation analysis [10], Gas chromatography [11], Liquid chromatography [12], matrix solid-phase dispersion [13], solid - phase extraction [14], and Spectrophotometry [15-18] are available in literature, but most of these techniques are costly and require trained staff. Spectrophotometry is a simple, sensitive rapid and versatile technique for quick determination of analyte. A few spectrophotometric methods based on the hydrolysis of kelthane to chloroform and determination of chloroform by Fujiwara method [15-18] are available, but all these methods require specially constructed apparatus and have poor sensitivity than the present method.

In the present a simple and more sensitive method is developed for the determination of kelthane. The reagent used in the present method is benzidine which increases sensitivity of the Fujiwara reaction. The method has been successfully applied for the determination of kelthane in environmental samples.

\section{Experimental}

Apparatus. A Systronics spectrophotometer 104 with 1 
$\mathrm{cm}$ matched quartz cell was used for all spectral measurement. A Systronics $\mathrm{pH}$ meter model 335 was used for $\mathrm{pH}$ measurement.

Reagents. All the reagents were of A.R./G.R.grade and double distilled deionised water was used throughout the study.

Stock solution of kelthane. (Tropical Agro system India Ltd.) $1 \mathrm{mg} / \mathrm{ml}$ solution or kelthane was prepared in alcohol. Working standards were prepared by appropriate dilution of the stock solution with alcohol.

Benzidine. (Merck, Germany) 1\% solution of benzidine in $25 \%$ alcohol was prepared.

Sodium hydroxide. $5 \mathrm{M}$ aqueous solutions.

Hydrochloric acid. $10 \mathrm{M}$ aqueous solution.

Pyridine, glacial acetic acid, n-hexane and ether solvent.

Procedure. An aliquot containing $2.0-30 \mu \mathrm{g}$ of kelthane was taken in a $25 \mathrm{ml}$-graduated tube. The solution was evaporated off up to $0.5 \mathrm{ml}$ on a water bath. To this $1 \mathrm{ml}$ of pyridine and $2 \mathrm{ml}$ of $5 \mathrm{M} \mathrm{NaOH}$ were added and thoroughly shaken. The contents were kept in water bath at $70^{\circ} \mathrm{C}-75^{\circ} \mathrm{C}$ for $\sim 3 \mathrm{~min}$. and shaken time to time. The yellowish-red colour solution obtained was cooled in ice-cold water bath and then decolourised with $2 \mathrm{ml}$ glacial acetic acid. To this yellow colour solution $2 \mathrm{ml}$ of $1 \%$ benzidine and $1 \mathrm{ml}$ of $10 \mathrm{M} \mathrm{HCl}$ were added and the content was allowed to stand for 10 minute. The volume was made up to the mark and the absorbance of the yellowish-red coloured dye was measured at $490 \mathrm{~nm}$ against a reagent blank.

\section{Colour Reaction of Kelthane}

The reaction was supposed to take place in four steps.

1) Kelthane was hydrolyzed by Sodium hydroxide to generate chloroform (I) and 4, 4-dichlorobenzophenone.

2) In this step chloroform reacted with pyridine in alkaline medium to form Schiff's base of glutaconic aldehyde (II).

3) In the third step, by addition of glacial acetic acid, the pink colour of Schiff's base of glutaconic aldehyde was converted in to the yellow coloured glutaconic aldehyde (III).

4) Yellow coloured Glutaconic aldehyde formed a purple red coloured polymethine dye (IV) with benzidine reagent in the fourth step (Mechanism 1).

\section{Results and Discussion}

Spectral Characteristic. All the spectral measurements were carried out against, reagent blank which showed negligible absorbance at $490 \mathrm{~nm}$ (Figure 1).

Adherence of Beer's Law, Molar absorptivity, and Sandell's sensitivity. Beer's law was obeyed over a con-
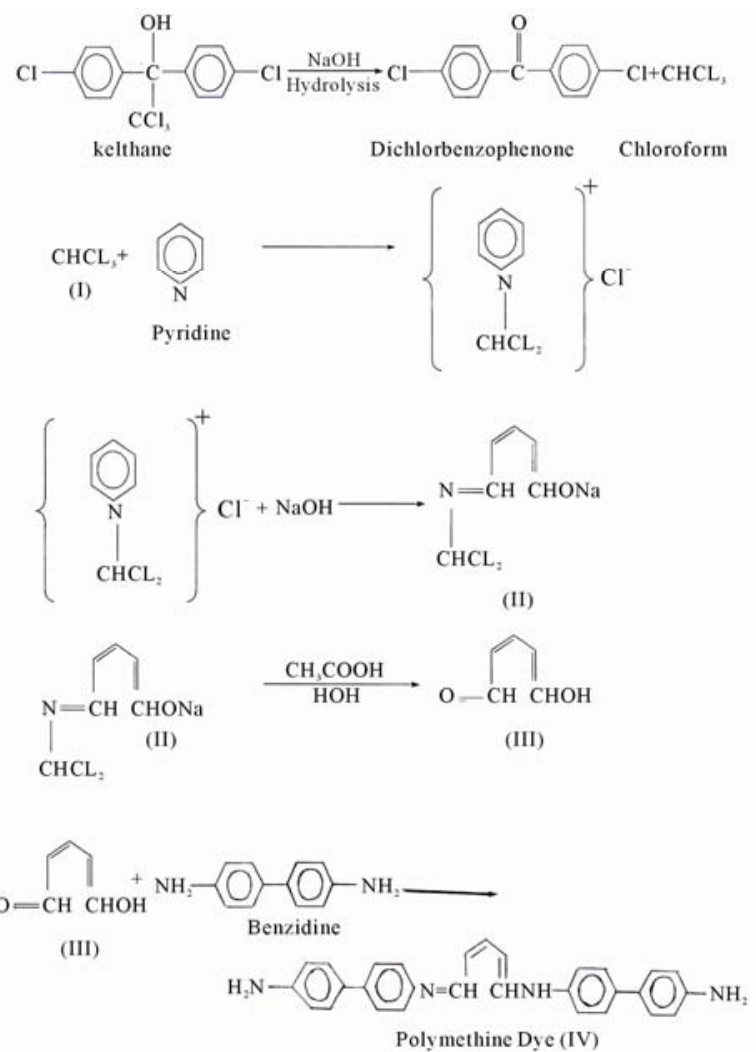

Mechanism 1

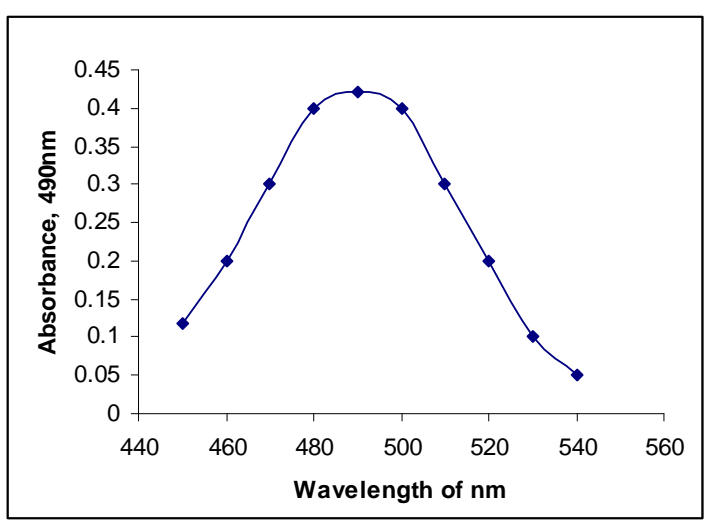

Figure 1. Absorption curve of kelthane.

centration range of $2.0 \mu \mathrm{g}-30.0 \mu \mathrm{g}$ (Figure 2) of kelthane per $25 \mathrm{ml}$ of final solution $(0.13-1.04 \mathrm{ppm})$. Molar absorptivity and Sandell's sensitivity were found to be $4.32 \times 10^{5} \mathrm{l} \cdot \mathrm{mol}^{-1} \mathrm{~cm}^{-1}$ and $0.022 \mu \mathrm{g} \cdot \mathrm{cm}^{-2}$ respectively.

Effect of reagent concentration. $1 \mathrm{ml}$ of pyridine and $2 \mathrm{ml}$ of $5 \mathrm{M} \mathrm{NaOH}$ were required for maximum colour intensity. Excess of $\mathrm{NaOH}$ made the solution slightly turbid. $2 \mathrm{~mL}$ of acetic is necessary for decolourisation of the red colour. Excess amount, however, does not affect the reaction. A minimum of $2 \mathrm{ml}$ of benzidine was required 


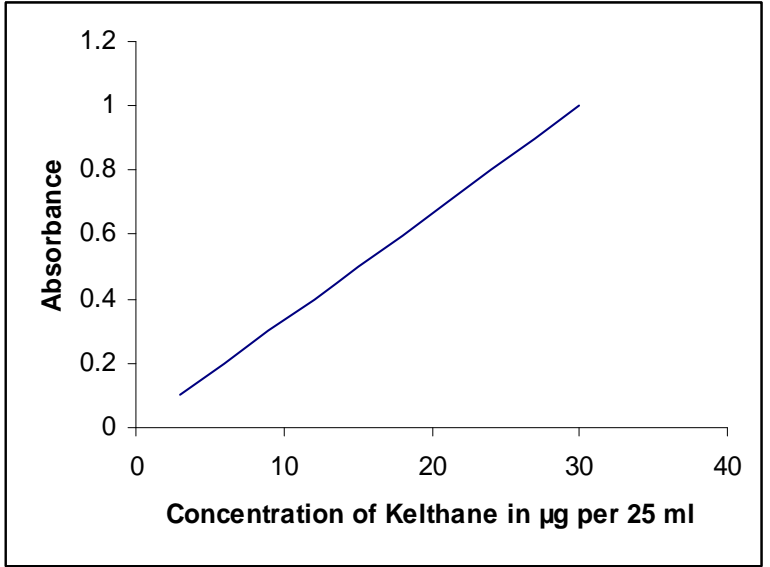

Figure 2. Calibration curve of kelthane.

for maximum colour intensity. Excess amount of benzidine decreases the colour intensity (Figure 3 ).

Effect of time and temperature. It was observed that heating the reaction mixture for a $\sim 3$ minutes in a water bath at $70^{\circ} \mathrm{C}-75^{\circ} \mathrm{C}$ gave maximum and constant absorbance value. The purple red colour dye was found to be stable for $\sim 10 \mathrm{~min}$. and thereafter showed gradual decrease in intensity with increasing time. (Figures 4 and 5).

Effect of pH. Maximum absorbance of the dye was observed when $\mathrm{pH}$ of the final solution was between 3 and 4 .

Precision. The precision of the method was checked by seven replicate analysis containing $25 \mu \mathrm{g}$ kelthane per $10 \mathrm{ml}$ of final solution. The standard deviation and relative standard deviation were found to be \pm 0.0033 and \pm $0.53 \%$ respectively.

Effect of foreign species. The validity of the method was assessed by investigating the effect of various co pollutants and polyhalogenated compounds on the determination of Kelthane by the developed method, by adding a known amount of these compounds to a solution containing $25.0 \mu \mathrm{g}$ Kelthane per $25 \mathrm{ml}$ of the final solution. The tolerance limit in ppm of interfering species was established, as the concentration required for causing an error of not more than $\pm 2.0 \%$ in the absorbance for Kelthane. The Results of these experiments are shown in Table 1, which showed that the method was found to be free from interference of various polyhalogenated compounds and metal ions, commonly found in the described samples. Trichloroacetic acid and chloroform gave positive interference. N-hexane and petroleum ether extracts from the vegetables and other samples have no interference.

\section{Application}

In Water Sample. $100 \mathrm{ml}$ of kelthane free water sample was taken and fortified with known amounts of kelthane

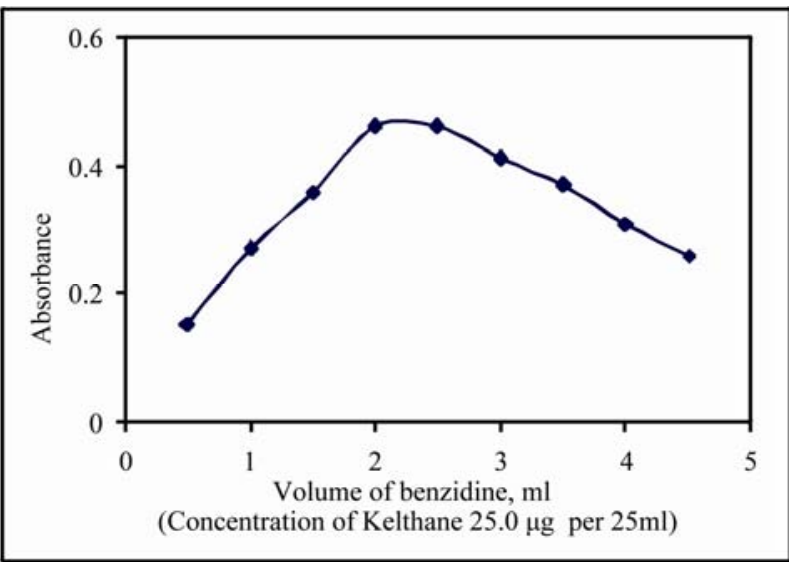

Figure 3. Effect of the concentration of benzidine solution.

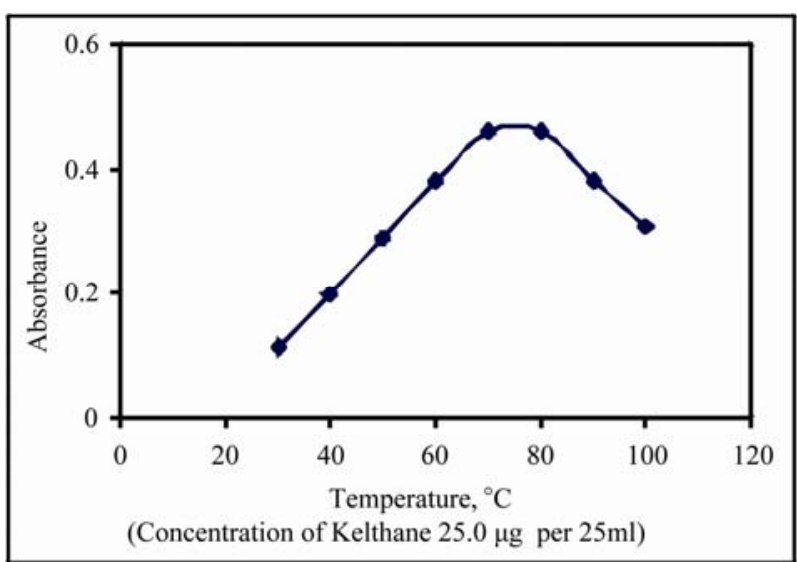

Figure 4. Effect of temperature.

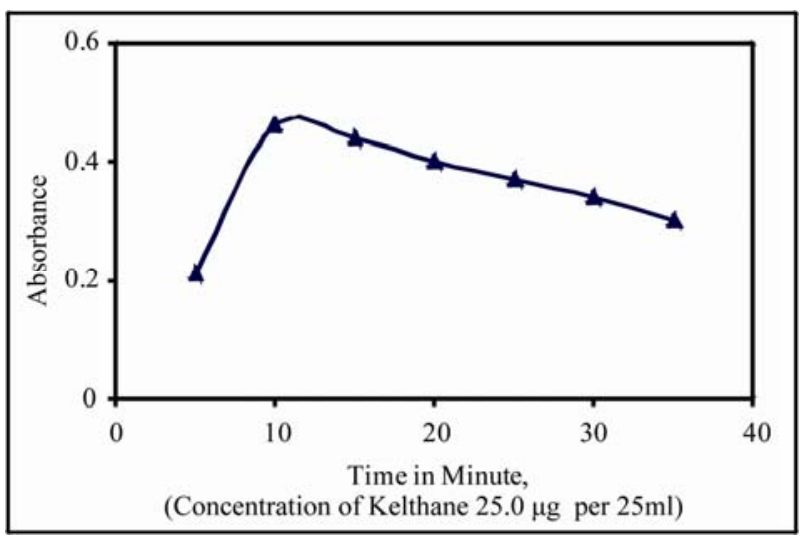

Figure 5. Effect of time.

and kept for $3-4$ h.. Then kelthane was extracted in $\mathrm{n}$-hexane. Hexane was evaporated off and kelthane was determined by the present as well the reported method [18]. The recoveries are shown in Table 2.

In Milk Sample. To assess the applicability of the method for the determination or kelthane in milk samples, known amounts of dicofol were added to the milk sample. 
Kelthane was extracted in n-hexane as reported [6] and determined by present as well as reported method [18]. The recoveries are shown in Table 2.

In Vegetables and Fruits Samples. Various vegetables and fruits samples such as tomato, beans grapes were weighed, crushed and then spiked with known amounts of kelthane and kept for $3-4$ h. Kelthane was extracted in n-hexane. Hexane was evaporated off and kelthane was determined by the present as well as reported method [18].The recoveries are shown in Table 2.

The comparison of the present method with other reported [15-18] method is shown in Table 3.

Table 1. Effect of foreign species: (Concentration of kelthane $25 \mu \mathrm{g} / 25 \mathrm{ml}$ ).

\begin{tabular}{|c|c|c|c|}
\hline Foreign species & Tolerance limit ppm* & Foreign species & Tolerance limit ppm* \\
\hline DDT & 1000 & $\mathrm{Cu}^{2+}, \mathrm{Cd}^{2+}$ & 1100 \\
\hline Carbaryl, Propoxur & 600 & $\mathrm{~Pb}^{2+}$ & 550 \\
\hline 2,4-D, 2,4,5-T & 450 & $\mathrm{NO}_{2}^{-}, \mathrm{Sn}^{2+}, \mathrm{Ca}^{2+}, \mathrm{Ni}_{2}^{+}$ & 430 \\
\hline Paraquat BHC & $\begin{array}{l}200 \\
150\end{array}$ & $\mathrm{Zn}^{2+}, \mathrm{Fe}^{2+}$ & 400 \\
\hline Malathion, $\mathrm{CCl}_{4}$ & 100 & $\mathrm{Hg}^{2+}$ & 300 \\
\hline Parathion & 50 & $\mathrm{PO}_{4}{ }^{3-}$ & 150 \\
\hline
\end{tabular}

* - The amount of foreign species causing error of $\pm 2 \%$.

Table 2. Recoveries of kelthane in various environmental samples.

\begin{tabular}{|c|c|c|c|c|c|c|}
\hline \multirow[t]{2}{*}{ S.N. } & \multirow[t]{2}{*}{ Sample } & \multirow[t]{2}{*}{ Kelthane added $\mu \mathrm{g}$} & \multicolumn{2}{|c|}{ Kelthane found ${ }^{*} \mu \mathrm{g}$} & \multicolumn{2}{|c|}{$\%$ Recovery } \\
\hline & & & Proposed method & Reported method [18] & Proposed method & Reported method [18] \\
\hline \multirow{3}{*}{1.} & Water $^{\mathrm{a}}$ & & & & & \\
\hline & A & 15 & 14.25 & 13.867 & 95.00 & 92.50 \\
\hline & B & 25 & 23.75 & 22.50 & 95.00 & 90.00 \\
\hline \multirow{3}{*}{2.} & Milk $^{\mathrm{a}}$ & & & & & \\
\hline & A & 15 & 14.12 & 13.13 & 94.13 & 87.50 \\
\hline & $\mathrm{B}$ & 25 & 23.46 & 20.63 & 93.84 & 82.50 \\
\hline \multirow{3}{*}{3.} & Tomato $^{\mathrm{b}}$ & & & & & \\
\hline & A & 15 & 14.42 & 14.25 & 96.13 & 95.00 \\
\hline & $\mathrm{B}$ & 25 & 24.26 & 24.375 & 97.44 & 97.50 \\
\hline \multirow{3}{*}{4.} & Beans $^{\mathrm{b}}$ & & & & & \\
\hline & A & 15 & 13.95 & 13.867 & 94.33 & 92.50 \\
\hline & $\mathrm{B}$ & 25 & 24.70 & 24.688 & 98.80 & 98.75 \\
\hline \multirow{3}{*}{5.} & Grapes $^{\mathrm{b}}$ & & & & & \\
\hline & A & 15 & 14.23 & 13.99 & 94.80 & 93.26 \\
\hline & B & 25 & 24.13 & 23.75 & 96.52 & 95.00 \\
\hline
\end{tabular}

* Mean of three replicate analysis; ${ }^{\mathrm{a}}$ Size of sample $100 \mathrm{ml}$. ${ }^{\mathrm{b}}$ Size of Sample $50 \mathrm{gm}$.

Table 3. Comparison of the proposed method with other spectrophotometric method.

\begin{tabular}{|c|c|c|c|c|c|}
\hline S.N. & Methods/Reagents & $\mu \max -\mathrm{nm}$ & Beer's law ppm & $\begin{array}{l}\text { Amount of } \\
\text { pyridine used } \mathrm{ml}\end{array}$ & Remarks \\
\hline 1. & $\begin{array}{c}\text { Fujiwara method } \\
\text { pyridine/ } \mathrm{NaOH}(15)\end{array}$ & 530 & $12.4-124$ & 5.0 & $\begin{array}{l}\text { Methods require special type } \\
\text { of distillation apparatus. }\end{array}$ \\
\hline 2. & $\begin{array}{c}\text { Modified Fujiwara } \\
\text { method/Pyridine/NaOH (16) }\end{array}$ & 530 & 200 & - & Poor sensitivity \\
\hline 4. & Benzidine (Present method) & 490 & $0.13-1.04$ & 1.0 & $\begin{array}{l}\text { Method is simple, more sensitive free from } \\
\text { inter-ference of other chlorinated hydrocarbon. }\end{array}$ \\
\hline
\end{tabular}




\section{Conclusions}

The data shown in Tables 2 and $\mathbf{3}$ clearly indicate that the present method is simple, rapid and more sensitive than other reported method for determination of kelthane. It can be successfully applied for the determination of kelthane in various environmental samples.

\section{Acknowledgements}

Authors are thankful to the Principal and Head, Chhatrapati Shivaji Institute of Technology Durg, Principal \& Head, Ashoka institute of Technology \& Management, Rajnandgaon for providing laboratory facilities and financial assistance.

\section{References}

[1] F. A. Gunther and L. R. Jeppson, "Modern Insecticide and World Food Production," Chapman and Hall, London, 1960, p. 129.

[2] R. F. Black, G. P. Kurtz and H. Baum, Association of Official Analytical Chemists Journal, Vol. 54, 1971, p. 1237.

[3] D. E. Ott, F. E. Hearth and A. Francis, "Determination of Kelthane and Its Dichlorobenzophenone Degradation Product by Thin-Layer Chromatography and Oscillopolarography," Bulletin of Environmental Contamination and Toxicology, Vol. 1, No. 5, 1966, pp. 181-186. doi:10.1007/BF01684095

[4] K. N. R. Rao and P. Surendranath, "Effect of Kelthane on $\mathrm{pH}$ Dependency of Lipases in Tissues of the Penaeid Prawn, Metapenaeus Monoceros (Fabricius) under Sublethal Exposure," Pesticide Biochemistry and Physiology, Vol. 39, No. 3, 1991, pp. 205-209. doi:10.1016/0048-3575(91)90115-3

[5] F. A. Gunther and J. D. Gunther, "Residue Reviews. Residues of Pesticides and Other Contaminants in the Total Environment," Zeitschrift für Allgemeine Mikrobiologie, Springer Verlag, New York, Vol. 21, No. 3, 1981, pp. 564-565.

[6] Z. Gunther, "Pesticides plant Growth Regulators and Food Additive," Academic Press, New York, 1964, pp. 263-271.

[7] F. A. Patty, "Industrial Hygiene and Toxicology," Intersciente Willey, New York, 1963, p. 1350.
[8] N. L. Morgan, "The Identification and Relative Retention Times of p,p'-kelthane and Its Breakdown Product p,p'-dichlorobenzophenone Using GLC," Bulletin of Environmental Contamination and Toxicology, Vol. 2, No. 5, 1967, pp. 306-313. doi:10.1007/BF01684379

[9] P. Manishankar, S. Viswanathan, M. A. Pustplatha and C. Rani, "Electrochemical Studies and Square Wave Stripping Voltammetry of Five Common Pesticides on Poly 3,4-Ethylenedioxythiophene Modified Wall-Jet Electrode," Analytica Chimica Acta, Vol. 528, No. 2, 2005, pp. 157-163. doi:10.1016/j.aca.2004.08.027

[10] D. D. Xu, L. L. Deng, Z. F. Chai and X. Y. Mao, “Organohalogenated Compounds in Pine Needles from Beijing City, China," Chemosphere, Vol. 57, No. 10, 2004, pp. 1343-1353. doi:10.1016/j.chemosphere.2004.09.016

[11] M. Kateina and S. J. Lehotay, "Evaluation of Common Organic Solvents for Gas Chromatographic Analysis and Stability of Multiclass Pesticide Residues," Journal of Chromatography A, Vol. 1040, No. 2, 2004, pp. 259-272. doi:10.1016/j.chroma.2004.04.017

[12] A. Jose, G. Jimena, P. J. Jimenez and J. M. Pavon, "Determination of Active Components in Insecticide Formulations by Liquid Chromatography and Resolution of Overlapped Peaks by Multivariate Analysis and Derivative Spectrophotometry," Analytica Chimica Acta, Vol. 321, No. 2-3, 1996, pp. 273-278. doi:10.1016/0003-2670(95)00578-1

[13] C. M. Torres, Y. Pico, M. J. Redonodo and J. Manes, "Matrix Solid-Phase Dispersion Extraction Procedure for Multiresidue Pesticide Analysis in Oranges," Journal of Chromatography A, Vol. 719, No. 1, 1996, pp. 95-103. doi:10.1016/0021-9673(95)00467-X

[14] J. Beltran, F. J. Lopez and F. Hernandez, "Solid-Phase Extraction of Pesticide Residues from Ground Water: Comparison between Extraction Cartridges and Extraction Discs," Analytica Chimica Acta, Vol. 283, No. 1, 1993, pp. 297-303. doi:10.1016/0003-2670(93)85235-C

[15] J. T. Hughes, "Notes," Analyst, Vol. 86, 1961, pp. 756-757. doi:10.1039/an9618600756

[16] H. P. Eduson, Association of Official Analytical Chemists Journal, Vol. 44, 1961, p. 183.

[17] I. Rosenthal, G. J. Frisone and F. A. Gunther, Journal of Agricultural and Food Chemistry, Vol. 5, 1957, p. 514.

[18] P. Shivhare and V. K. Gupta, "Pesticide Determination, Colorimetric Microdetermination of the Acaricide 4,4'Dichloro- $\alpha$-(trichloromethyl)benzhydrol (FW-293)," Fresenius' Journal of Analytical Chemistry, Vol. 343, 1992, p. 612 doi: $10.1021 / \mathrm{j} f 60077 \mathrm{a} 003$ 